\title{
Distribution and Current State of Rare and Endangered Tulips (Liliaceae) Arid Zones of Uzbekistan
}

\author{
Ozodbek S. Abduraimov ${ }^{1,2}$, Habibullo F. Shomurodov', Sultankul A. Daniyarov ${ }^{3}$, \\ Odilbek T. Mamatkasimov', Muxriddin I. Teshaev² \\ ${ }^{1}$ Institute of Botany Academy Sciences Republic of Uzbekistan, Tashkent, Uzbekistan \\ ${ }^{2}$ National University of Uzbekistan, Tashkent, Uzbekistan \\ ${ }^{3}$ Department of Ecology and Geography, Gulistan State University, Gulistan, Uzbekistan \\ Email: ozodbek88@bk.ru
}

How to cite this paper: Abduraimov, O.S., Shomurodov, H.F., Daniyarov, S.A., Mamatkasimov, O.T. and Teshaev, M.I. (2020) Distribution and Current State of Rare and Endangered Tulips (Liliaceae) Arid Zones of Uzbekistan. American Journal of Plant Sciences, 11, 736-744.

https://doi.org/10.4236/ajps.2020.115053

Received: April 9, 2020

Accepted: May 24, 2020

Published: May 27, 2020

Copyright $\odot 2020$ by author(s) and Scientific Research Publishing Inc. This work is licensed under the Creative Commons Attribution International License (CC BY 4.0).

http://creativecommons.org/licenses/by/4.0/

\begin{abstract}
Central Asia is considered to be the primary center of origin and diversity for the genus Tulipa L. (Liliaceae). The article considers the species of rare and endemic Tulipa L. species in the arid regions of Uzbekistan. There are nine registered species of the genus Tulipa. In the course of the study, the demographic indicators of the modern population of 39 populations were evaluated. 39 populations of the studied species were identified, most of which grow in the composition of the wormwood formations characteristic of the Turanian floristic province.
\end{abstract}

\section{Keywords}

Tulipa, Population, Biodiversity, Plant Communities, Current State, Rare and Endemic

\section{Introduction}

The unique plant riches of our country require attentive and careful treatment. Due to the strengthening human press on the environment many became rare, areas and numbers of their populations decrease natural renewal is violated. It especially concerns beautifully flowering species, which suffer not only from pasture, haymaking, economic assimilation of lands, but also from collection for the bouquets, and often bulbs, for sale, by people.

The genus Tulipa L. (Liliaceae) has at least 87 species. These are divided into four subgenera, Tulipa, Clusianae (Baker) Zonn., Eriostemones (Boiss.) van 
Raamsd., and Orithyia (D. Don) Baker, and twelve sections [1]. Genome size and the presence of nearly complete crossing barriers between the sections [2] [3] confirmed the close relationships of the species within the different sections. Tulips occur naturally in southern Europe, North Africa, the Middle East, and Central Asia, including Western China. The Tien Shan and Pamir-Alay mountain ranges in Central Asia are believed to be the primary gene centers for the species [4] [5], with the Caucasus as a secondary centre. Most species have the same basic chromosome number, $2 \mathrm{n}=2 \mathrm{x}=24$. However, the somatic DNA 2C value is shown to range from 32 to 69 picograms for the diploids [1]. They are popular spring-flowering garden plants, millions of bulbs are sold annually and over 5000 cultivars have been registered [6].

Tulipa L. genus is represented by 63 species in Central Asia [7]. From the 63 species in Uzbekistan 34 are grown, Kazakhstan-37, Kyrgyzstan-22, Tajikis$\tan -24$, and in Turkmenistan-16 species. 8 species out of 34 members of the genus occur in Uzbekistan, native to arid habitats, where the amount of annual atmospheric condensation does not exceed 120 - $140 \mathrm{~mm}$ per year. The species are: Tulipa lehmanniana Mercklin, T. korolkovii Regel, T. buhseana Boisser, T. borszczowii Regel, T. sogdiana Bunge, T. biflora Pall, T. turkestanica Regel, T. sharipowii Tajibaev, T. intermedia Tojibaev, JJ. De Groot \& N. M. Naralieva, T. micheliana Hoog [8] [9] [10] [11].

At present, the populations of the species of Tulipa where came from Central Asia are decreasing. The study and evaluation of the current distribution of species of Tulipa in the Central Asian region, the number and reasons for their disappearance are very important. Wild tulips are the national property of not only Uzbekistan, Kazakhstan and Kyrgyzstan, but also of the mankind, since they have been used in decorative horticulture all over the world, especially in Holland, for a long time.

Tulipa lehmanniana, T. buhseana, T. biflora, T. borszczowii and T. sogdiana are genuine desert species from the aforementioned species. The area of the first three species covers of Turan lowland and reaches to northern China (Kashgar), and the other two species are strict endemic of Turan phyto-geographical region. Two species-recently described from Fergana Valley-T. sharipowii and T. intermedia grow on gray-brown soils of the southern foothills of the Kurama Range (Western Tien-Shan). And finally, the last endemic species of Central Asia-T. micheliana, mainly distributed in the northwest of the Pamir-Alay and Kopetdag, the westernmost border of its range, comes in Kyzylkum (Nurata relict mountains and Kokchatau). T. lehmanniana, T. korolkovii, T. sharipowii, $T$. intermedia and T. micheliana are listed in the Red Book of the Republic of Uzbekistan from aforementioned species [12].

Wild tulips are the most impressive of all diversity of flora of Uzbekistan. In the last decades, as a result of intensive anthropogenic impact, the range and population numbers of many tulip species have considerably declined. The current Red Data Book of Uzbekistan [12] includes 18 species of Tulipa, 20 species are protected in national parks and nature reserves. But none of the Central 
Asian tulips have been included in the IUCN Red List of Threatened Species (2011) [13] [14].

T. buhseana was included in the previous editions of the Red Data Book of Uzbekistan $(1998,2006)$. At present, according to progressive status of populations and for lack of threats of disappearance, this species was excluded from the Red Data Book [12].

T. sogdiana was included in previous editions of the Red Data Book of Uzbekistan $(1984,1998,2006)$. At present, according to the progressive status of populations and for lack of threats of disappearance, this species was excluded from the Red Data Book [12].

T. turkestanica was included in previous editions of the Red Data Book of Uzbekistan $(1984,1998,2006)$. At present, according to the progressive status of populations and for lack of threats of disappearance, this species was excluded from the Red Data Book [12].

\section{Purpose of the Study}

Evaluating the modern status of rare genus of Tulipa L. species, spread in arid regions of Uzbekistan.

\section{Materials and Methods}

Our field researches were conducted in 2012-2020 on the arid zones of Uzbekis$\tan$. These studies were carried out using geobotanical and population methods. We have defined the area and number of tulip populations, registered their coordinates, altitude, exposition, characteristics of the terrain, soil and vegetation. All data are loaded into the GIS with ArcGIS computer program, and have created the distribution map 39 populations. Observations were made in all populations during the study.

Transects were laid with a length of $10 \mathrm{~m}$, they were divided into platforms of $1 \mathrm{~m}^{2}$. Each population contains from 20 to 50 plots of $1 \mathrm{~m}^{2}$ (Figure 1). Ontogenetic structure of coenopopulations was defined as the ratio in coenopopulations of individuals of different ontogenetic conditions. For the counting unit was taken individual. The obtained results were analyzed on the basis of "Past" and "Statistic 10 " programs.

\section{Result and Discussion}

During the study, the demographic characteristics of genus of Tulipa L. species, which were spread in arid regions of Uzbekistan were evaluated. 70\% of Uzbekistan's territory is composed of arid regions. The decline in the number of rare and endangered species in arid regions of Uzbekistan is inextricably linked with their inadequacies, the absence of reserves and national parks in these areas, and the ever-increasing antropogenic pressure. Here are tulips, Tulipa intermedia, T. korolkovii, T. lehmanniana, T. micheliana, Tulipa scharipovii included in the Red Book of the Republic of Uzbekistan [12]. 


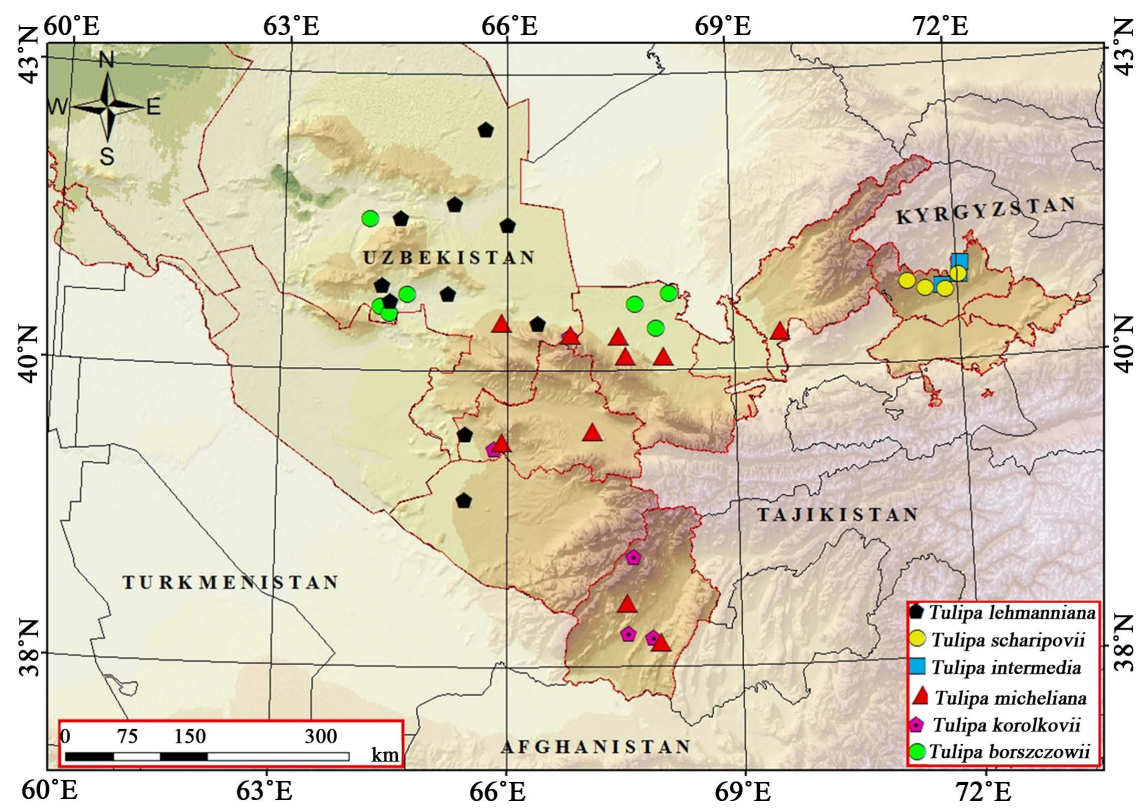

Figure 1. Distribution map of species of Tulipa L. arid zones of Uzbekistan.

During the 2012-2020 study, modern conditions of T. borszczowii-7, $T$. intermedia-3, T. korolkovii-5, T. lehmanniana-10, T. micheliana-10, T. scharipovii-4 populations were evaluated (Figure 1). The rarity of these species was determined by their distribution, endemic and Red Book status.

In Uzbekistan, the tulip species have long been of great interest to humans. People planted it in their gardens as ornamental plants.

Tulipa borszczowii-One of the rare species of the genus in Uzbekistan. The tulip is described by Edward Regel in 1868 based on the collection of 1857 gathered in Karakum near the Aral Sea by a well-known Russian botanist Ilya G. Borszchow. It was believed that it is so rare in Uzbekistan that in some sources it is cited as endemic to Kazakhstan [15]. However, in the Central Herbarium of the Institute of Botany of the Academy of Sciences of Uzbekistan (TASH) there is a herbarium specimen of the species, collected in 1965 by V. Makarova and A. I. Vvedensky. It was assembled in the southeastern part of Kyzyl-Kum in the vicinity of the Chardar reservoir. During our 2012-2020 study, 7 new growth points were recorded.

T. intermedia-The species was described 2014 by Tojibaev, JJ. De Groot \& N. M. Naralieva. T. intermedia, collected is the Ferghana Depression is described. It is species is endemic to the foothills surrounding the northern side of the Ferghana Depression. Morphologically, T. intermedia takes and intermediate position between T. scharipovii and T. talassica Lazkov [16]. From the species in a close proximity, T. scharipovii, it differs by non-coriaceous and strongly prolongated bulb tunics, its pubescence of tunics, sorter stem, the shape of outer petals and filaments (which are much longer than in T. scharipovii), and by its pale yellow (not green) bottle-shaped ovary. T. intermedia also differs in ecology, growing in Artemisia steppe on the plains and in low foothills with gravelly 
slopes. The flowering occurs in March-April.

T. korolkovii-The species was described in 1875 by Edward L. Regel. The natural distribution area of T. korolkowii is North-Western, Western and South Pamir-Alay, South-Western Tien Shan. Due to its dwarf habitus, elegant cup-shaped bright red flowers and two-colored stamen filaments (black in the lower part and red in the top) it differs from other species. Plants growing on dry stony southern slopes are $7-10 \mathrm{~cm}$ long, on northern slopes up to $20-25$ $\mathrm{cm}$. Flowering in March-May, depending on altitude.

T. lehmanniana-The species was described in 1854 by Russian botanist K.E. Mercklin on specimens collected between Bukhara and Kermine. It is widespread on the territory of Turan floristic province: in Kyzylkum and Karakum deserts, on the piedmont plains of Western Tien Shan and Pamir-Alay, in Ferghana Valley, Kopet-Dag, Badhyz, Iran, Pakistan, Northern Afghanistan, Northern Muyunkums and south-western part of Betpakdala desert. Grows in sandy and clay deserts, on piedmonts, in stony-sceleton slopes and gypsaceous rocks on outlier mountains. It is one of the most beautiful species of Central Asian wild tulips, distinguished by fineness and bright various colors of flowers. The flowering occurs in March-April.

T. micheliana-The species was described in 1902 by Thomas Hoog on specimens collected in 1900 by German botanist Paul Sintenis near Ashkhabad. It is widespread in North-Western Pamir-Alay and Kopet-Dag, in Uzbekistan, Tajikistan, Turkmenistan and Iran. In Uzbekistan, this tulip occurs on the Nuratau mountains, on Zaravshan, Gissar and Kugitang ridges. It grows on stony-sceleton and clay slopes of foothills and low mountains. It is distinguished by leaves with violet stripes. The flowering occurs in March-April.

T. scharipovii-2009 years within the bounds of the Fergana valley (Uzbekistan) a new tulip species from Tulipa subgenus, T. scharipovii Tojibaev, has been found on the southern slopes of the Kurama and Chatkal ranges [8]. The species is named after the Uzbek tulip scientist, A. Kh. Scharipov. By its morphological structure, the new species shows its relationship to T. ferganica Vvedensky The flowering occurs in March-April (Figure 2).

During the study, the density of populations in the arid regions of Uzbekistan has been studied. It should be noted that the species of Tulipa L. species is currently decreasing dramatically. This is due to regular livestock feed and geological prospecting.

Species density and area were determined based on generally accepted geobotanical and population methods. These methods help in conducting several years of monitoring of the species. Their level of reliability will be high [11].

T. borszczowii and T. lehmanana species are spread in deserts of Uzbekistan. The high density of densities was found to be high in these species. That is, $T$. borszczowii showed that the figure was $2.85-17.7$ per $1 \mathrm{~m}^{2}$, and T. lehmanniana was $1.95-17.76 \mathrm{pcs} 1 \mathrm{~m}^{2}$.

The distribution of T. korolkovii and T. micheliana is relatively wider. These species are spread in the arid regions of Uzbekistan as well as in the middle part 


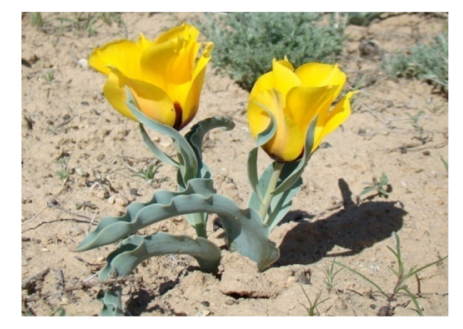

Tulipa borszczowii Regel

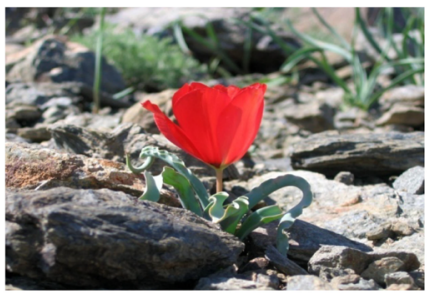

Tulipa korolkovii Regel

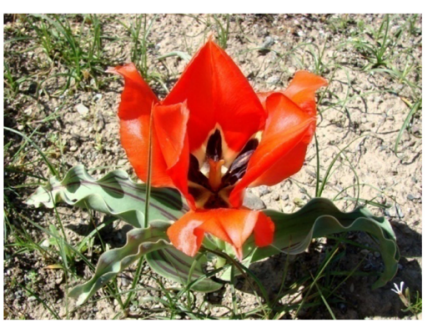

Tulipa micheliana Hoog

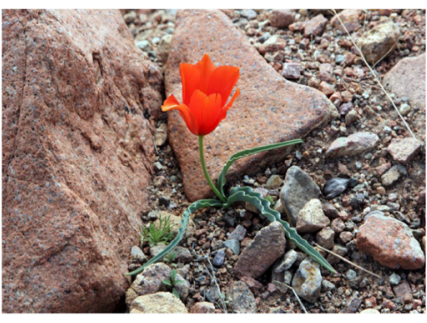

Tulipa intermedia Tojibaev et al.

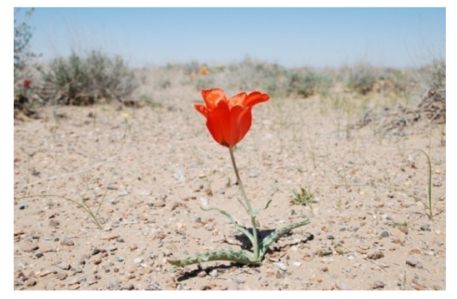

Tulipa lehmanniana Mercklin

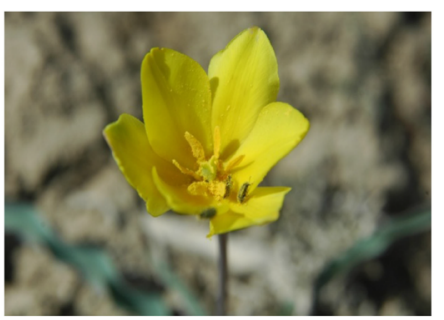

Tulipa scharipovii Tojibaev

Figure 2. Rare and endangered species genus of Tulipa arid zones of Uzbekistan.

of the mountains. Population of these species is regularly affected by livestock breeding and the collection of flowers by humans. Both species were found to be between 1.25 to $4.95 \mathrm{pcs} 1 \mathrm{~m}^{2}$ (Figure 3).

One of the main reasons for the decline of T.micheliana populations in populations is that we can not grow vegetatively in natural conditions. Among the species studied are the most narrow, T. intermedia and T. scharipovii, which are the endemic flora of Uzbekistan. The density of these species varies from 1.6 to 3.75 ( T. intermedia) and 3.2 to 5.1 per square $1 \mathrm{~m}^{2}$ (Figure 3).

The problem of the protection of the environment and flora is of great and vital importance for the whole humanity. Using natural resources, people negatively influence on the natural age-old landscapes. Development of industry and agriculture, extensive reclamation of natural territories lead to the breach of ecological balance. As a result of this, the danger of impoverishment of species composition of flora and loss of plants' gene fund increases. Disappearance of any species causes irreversible consequences, as wild plants make the feedstock for the creation of valuable varieties of many cultures. There are about 4500 species of wild higher plants and over 2000 species of fungi in the territory of Uzbekistan. About 400 of them are rare, endemic and relict species $(10 \%-12 \%$ of flora). Effective measures are necessary for their protection. Although the status of flora protected in the reserves is rather good, natural stocks of wild species 
Tulipa borszczowii

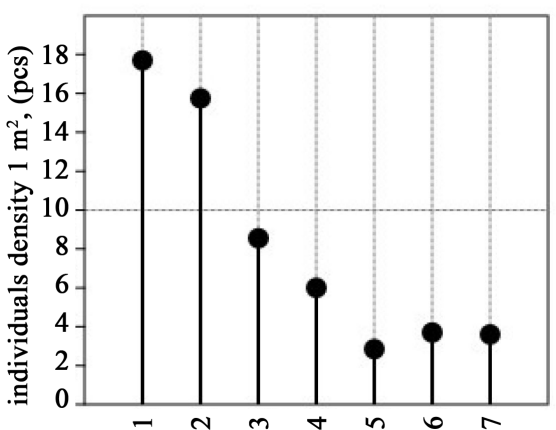

(a)

Tulipa korolkovii

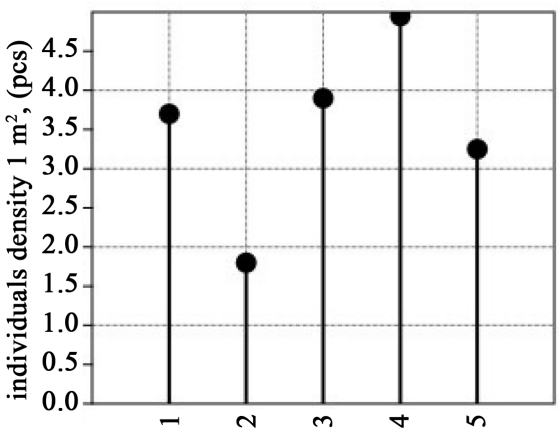

(c)

Tulipa micheliana

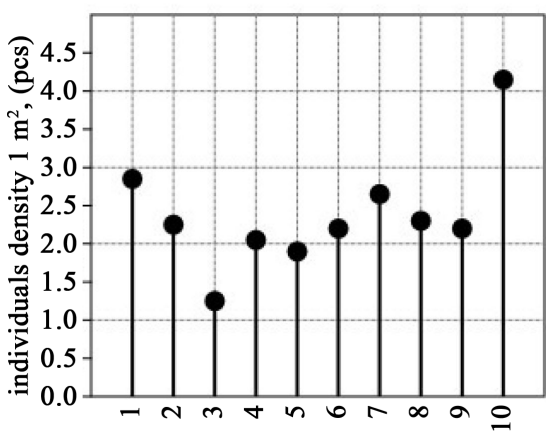

(e)
Tulipa intermedia

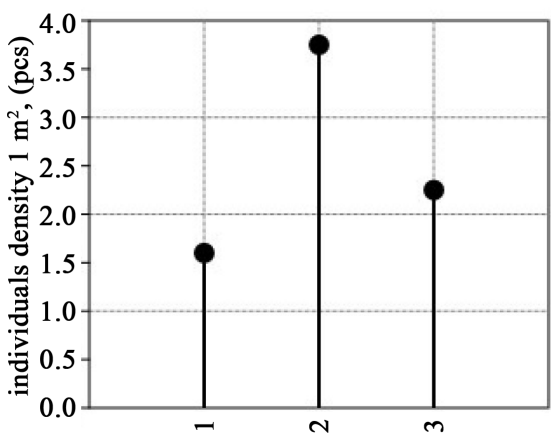

(b)

Tulipa lehmanniana

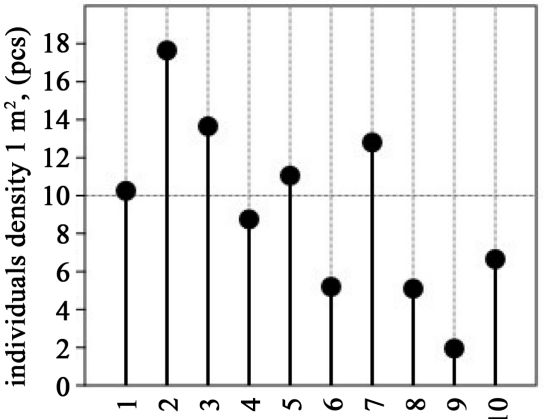

(d)

Tulipa scharipovii

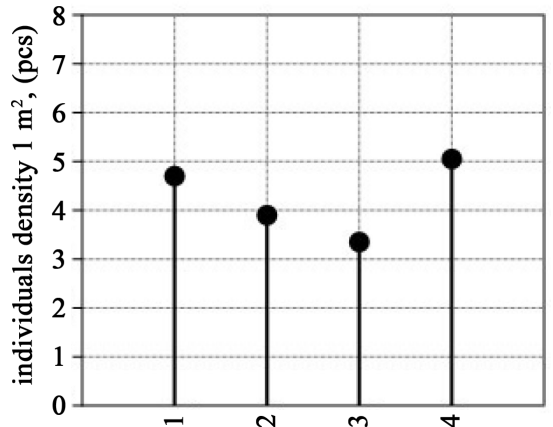

(f)

Figure 3. Individuals density $1 \mathrm{~m}^{2}$ (pcs) of the studied populations genus of Tulipa L. (Uzbekistan). (a)—Tulipa borszczowii; (b) - T. intermedia; (c) - T. micheliana; (d) $-T$. lehmanniana; (e)-T. micheliana; (f) - T. scharipovii.

have sharply reduced. Thus, intensified industrial stocking caused reduction of areals of tulip-Tulipa. A considerable number of species are on the verge of disappearance. Uncontrolled collection of rare medicinal and eatable plants (particularly bulbous, bulb-tuberiferous, rhizomatous dug out with under-ground organs) taking more and more threatening scale, causes great damage to wild flora. Thus, all studied populations are viable with a sufficient number of generative individuals providing seed reproduction. Minor fluctuations are observed only 
in the proportion of the same ontogenetic conditions. Ontogenetic structure of populations is normal, in most cases incomplete due to the absence of senile individuals. Most of them (60\%) have a left-sided type, coincide with the characteristic theoretical ontogenetic spectrum and reflect the biological features of the species. The deviation of the ontogenetic spectrum of specific populations from the characteristic one is due to the ecological-phytocenotic habitat conditions.

\section{Conclusions}

The species is able to successfully maintain its abundance in the prevailing environmental conditions under certain types of permanent effects on their habitat. Population size in the study area is sharply decreasing everywhere. These species are unstable when grazing, recreational load, mowing, gathering on bouquets. They can be preserved in natural places of growth in specially protected natural areas (reserves, botanical reserves and natural monuments). For each specific population of plants, specific measures should be developed considering their ecological and biological features.

All the species studied are included in the Red Book of the Republic of Uzbekistan [12]. However just registering species on the page of the Red Book is not yet a guarantee of preserving its genetic fund in full. Special legislative acts and effective control of their execution are necessary. Only the involvement of all citizens of the Republic in the cause of protection of nature and its flora can allow achieving desired results. Only in this way the live nature can be saved for the next generations.

\section{Acknowledgements}

The current research is done under the project PZ-20170919165 "Cadastre of rare and endangered species of vascular plants of Navoi and Bukhara region". The authors express their gratitude to Dr. K. Sh. Tojibaev and the employees of the National Herbarium of the Institute of Botany of the Academy of Sciences Republic of Uzbekistan, for making the data on the distribution and photos of genus of Tulipa L. We are also grateful to junior researcher U.Kh. Kadirov for the assistance in mapping the distribution of genus of Tulipa L.

\section{Conflicts of Interest}

The authors declare no conflicts of interest regarding the publication of this paper.

\section{References}

[1] Zonneveld, B.J.M. (2009) The Systematic Value of Nuclear Genome Size for All Species of Tulipa L. (Liliaceae). Plant Systematics and Evolution, 281, 217-245. https://doi.org/10.1007/s00606-009-0203-7

[2] Van Raamsdonk, L.W.D. (1992) Biosystematic Studies in Tulipa Subgenus Eriostemones. Plant Systematics and Evolution, 179, 27-41. 
https://doi.org/10.1007/BF00938017

[3] Van Raamsdonk, L.W.D. and De Vries, T. (1995) Species Relationships and Taxonomy in Tulipa subgenus Tulipa L. Plant Systematics and Evolution, 195, 13-44. https://doi.org/10.1007/BF00982313

[4] Beshko, N.Yu. and Tojibaev, K.Sh. and Batoshov, A.R. (2013) Tulips of the Nuratau Mountains and South-Eastern Kyzylkum (Uzbekistan). Stapfia, 99, 198-204.

[5] Botschantzeva, Z.P. (1962) Tulips: Taxonomy, Morphology, Cytology, Phytogeography, and Physiology. Balkema, Rotterdam, 1-230. (English Edition Translated by Varekamp, H.Q. 1982)

[6] Van Scheepen, J. (1996) Classified List and International Register of Tulip Names. KAVB, Hillegom.

[7] Vvedensky, A.I. and Kovalevskaja, S.S. (1971) Tulipa L. In: Vvedensky, A.I., Ed., Conspectus Florae Asiae Mediae, Vol. 2, Acad. Sci. Press, Tashkent, 94-109.

[8] Tojibaev, K.Sh. and Kadyrov, R.U. (2010) Tulips of Uzbekistan. Shark Press, Tashkent, $224 \mathrm{p}$.

[9] Tojibaev, K. and Beshko, N. (2014) Reassessment of Diversity and Analysis of Distribution in Tulipa (Liliaceae) in Uzbekistan. Nordic Journal of Botany, 33, 224-234. https://doi.org/10.1111/njb.00616

[10] Abduraimov, O.S., Shomurodov, H.F. and Abduraimov, A.S. (2017) Distribution Pattern and State of Coenotic Population of Tulipa lehmanniana Merckl. in Kyzylkum Desert Conditions (Uzbekistan). American Journal of Plant Sciences, 8, 288-296. https://doi.org/10.4236/ajps.2017.82020

[11] Abduraimov, O.S., Shomurodov, H.F. and Daniyarov, S.A. (2018) The Current State of Cenopopulation of Tulipa micheliana Hoog in Uzbekistan. American Journal of Plant Sciences, 9, 1725-1739. https://doi.org/10.4236/ajps.2018.98125

[12] Khasanov, F.O. (2019) The Red Data Book of the Republic of Uzbekistan 2019. Vol. 1. Plants and Fungi. Chinor ENK, Tashkent, 152-156.

[13] The IUCN Red List Categories and Criteria. Version 3.1 2001, 2012. http://www.iucnredlist.org

[14] The IUCN Red List of Threatened Species 2011. http://www.iucnredlist.org

[15] Ivashchenko, A.A. (2005) Tulips and Other Bulbous Plants of Kazakhstan. Two Capitals, Almaty, $192 \mathrm{p}$.

[16] Tojibaev, K.Sh., de Groot, J.J. and Naralieva, N.M. (2014) Tulipa intermedia sp. nov. (Liliaceae) from the Ferghana Depression, Uzbekistan. Nordic Journal of Botany, 32, 546-550. https://doi.org/10.1111/njb.00374 